\title{
Delima of the Fixation and Determination of Qibla
}

\author{
* Dr Rashida Parveen \\ ** \\ Prof. Dr. Muhammad Amin
}

\begin{abstract}
ABSRACT
Islamic Shari'ah is universal, all its injunctions are based on comfort, easiness and openness, instead of deep philosophical and mathematical delicacies. This is only because of the fact that the jurisdictions of the "Islamic Shari'ah" are the sea and land, the black and red including all residents of these regions. Furthermore, if the obligations of Islam e.g.,"الصلوة "الصوم" etc, are obligatory for the "residents"of cities and other educated people, exactly in the same way these are for the inhabitants of villages, islands and the ignorant individuals too. Subsequent upon this, it is very much desired by reason, wisdom and special blessing of Allah (S.W.T) that the "Shari Ahkam" which are so common, the same should not be made dependent on mathematical delicacies and astronomical instruments. So that all and sundry may perform their obligations easily and with full satisfaction

The ambiguities raised by Allama Inayatullah Al-Mashriqi and some Aryan Hindu,s authors regarding the under reference topic named "Delima of the fixation (Determination) of Qibla" shall thoroughly be discussed. This paper will argue and let those facts go through the researching and inductive stages to explore the valuable realities. Efforts would be exerted to arrive at the conclusion that in the Delima of Fixation (Determination) of "Qiblah" all of "تبع تابعين " our religious forefathers (predecessors) e.g. "تابعين", "صحابر" shall be strictly followed. It means, that we must fix (determine) the "Qibla'h's" position (direction) on account of only estimation (تقليد و تحرى) through the significant signs of the natural phenomenon (i.e) the rising and setting of the Sun, the Moon, besides identification of some of the stars; and not through the man made, scientific and mythological hypothesis.
\end{abstract}

Key Words: Qibla, Delima of Fixation, Estimation, Islamic Shariah.

The "Delima of the Fixation (Determination) of Qibla" has been a very important topic among the Muslim and even some nonMuslim scholars since

\footnotetext{
*hairperson Department of Islamic Studies women university Mardam.
$*^{*}$ Ex Chairman Department of Islamic Studies, AWKUM/Visiting Professor Women University, Mardan.


long. However, it attracted the attention of all and sundry on the day when ambiguities were created for the first time ever by Allama Inayatullah Al-Mashriqi ${ }^{1}$-and some Aryan Hindu writers in their writings about the accuracy of the direction of the "Qibla". Being very critical to this situation, some more added that the Muslims, by facing the "Qibla" at the time of offering their prayers are committing a sort of Idol worshiping or idolatry which is not permissible in Islam.

From this introduction, it is quite clear that fixation (Determination) of Qibla to which all Muslims have to stand in its direction while offering prayer, the Shari'ah must have identified a simple and easy practicable method for that purpose. This is why Allah says:

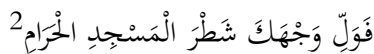

"Turn your faces towards the Sacred Mosque (Ka'aba)."

All Muslims are directed to turn their faces in five prayers daily, to ward "Ka'aka" where ever they may be. When such is the case, then "Shari'ah" would have compulsorily adopted a simple and easy way which can be practiced by each person whether living in a village or a city.

Explaining the above cited verse of Al-Quran, the Prophet Muhammad (SAWS) says:

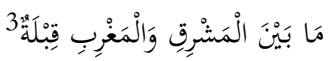

"The Qibla is between the East and the West".

\section{From this "Hadith" the following points are derived:}

1. In the fixation and determination of Qibla, it is not mandatory to carry out extreme research or scientific analytical study in this regard, but the Prophet (SAWS), pointing to the middle of the East and the West determined the direction of "Ka'aba". He (SAWS) said ," the whole of the South is "Qibla" (for those living in Madina).

2. This is not proved from any of Hadfith or the practice of the Prophet (SAWS) as well as his companions to have used any instruments or metrological technology for fixing the "Qibla" while constructing mosques. It was rather usually done only through estimation after having 
assessed the effects/signs, rising, setting of the Sun, Moon, and identification of the positions of some stars.

\section{Critical \&Analytical Study of the Views of Allama Inayatullah Al-Mashriqi Regarding Ambiguity in the Definition of Qibla:}

Among the scholarly circles Allama Inayatullah Al-Mashriqi is a well known figure who is not in need of any introduction. In the past, he had written an article on the incorrect position of the Qibla in the mosques of India. All of his information was based on his mathematical and astronomical principles and rules.All of his reservations had been properly and very correctly responded by the religious scholars of that time including Mufti Muhammad Shafi and Maulana Ahmad Ali Lahori. From the same discourse only the following one quotation is being reproduced as it follows:

" It can quite vividly be observed from this map, that in all mosques of India except Surat Nagpur, Katak etc, which are lying at 80 degree latitude on which is also lying Makka Mua'azamah, the Qibla directions of all the new mosques of India are incorrect. There is no single mosque among them in which the praying individuals have ever offered their prayers toward the correct direction of the Qibla till this day. The Qiblah of the inhabitants of Lahore and Amratasar is "Bait AlMaqdas", that of the residents of Rawalpindi is Baghdad/Damascus and that of Peshawarites it is Beirut, that of Delhi Bosher, that of Multanis it is Kofa, that of Karachites it is Madina, that of Madrasis it is Eden and that of the inhabitants of Bombay it is Swakan Port etc."4

It is evident from the above cited quotation that during praying position which ever direction is faced by the person offering prayer, that is called to be the Qiblah. Due to this conception the decision that the Qibla of the people of Lahore and Amratsar is Bait Al-Maqdas, that of the people of Rawalpindi it is Baghdad and Damascus.

\section{Eradication of this Ambiguity with a solid Proof:}

With ample humbleness the above-cited concept of Allama Inayatullah Al-Mashriqi is contradicted by the author in principle. 
The author, very humbly takes the opportunity to say that when ever any difference in the Longitudes and Latitudes of two cities is found, there would compulsorily exist difference in the "Qibla" of the two.

It is once again reiterated that Allama Mashriqi had identified Baghdad and Damascus to be the Qibla of the residents of Rawalpindi, which are different from each other in Latitude and Longitude. So it is understood that the Qibla of such two cities, the Longitudes and Latitudes of which are different from each other cannot happen to be Qabla for any one of the two. Imam Radhi's Substantiation in this regard Commenting upon the proofs of fixation (Determination) of Qibla, Imam Radhi- ${ }^{5}$ write:

$$
\begin{aligned}
& \text { و اما الطريقة اليقينية وهى الوجوها الهنكورتهف كتب الهيئة قالوا: سمة } \\
& \text { القبلة نقطة التقاطع بيندائرةالافن، وبين دائرةاعظيهة تمربسهةرؤوسنا } \\
& \text { ورؤوس اهل مكة، و انحر اف القبلة من دائرة الافقى ما بيي سمة القبلة }
\end{aligned}
$$

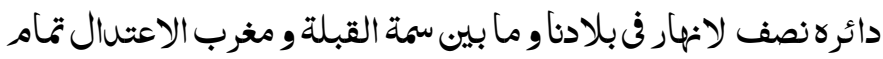

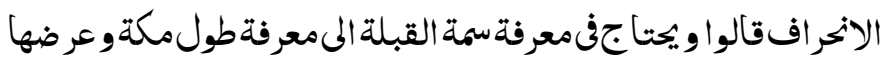

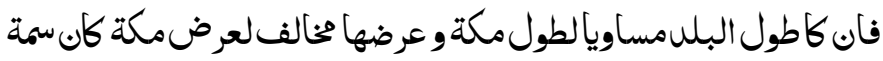

$$
\begin{aligned}
& \text { قبلتها على خط نصف النهار فأن كان البلاد شماليا فألى الجنوب وان كان كان }
\end{aligned}
$$

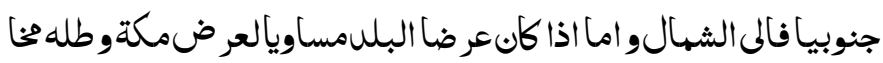

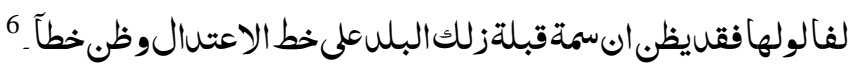

" For the fixation (determination) of Qibla, the authentic and genuine method is based on those causes which have been discussed in the books of Astronomy They say,"the direction of Qibla is at that point which intercepts the (vacuum) between the circle of the "horizon" and that big circle which passes over our heads and the heads of the people living in Makka. (The place of) Deviation from Qibla is that arc which is coming out from the horizon. In our lands (countries) there is circle of midday (appearing at mid day time) which is between the direction of Qbla and the West (Maghrib), $t$ becomes leveled(balanced) occurring complete deviation. They (further) said, that we first of all need to know the longitude and latitude of Makka, provided we want to know the direction of Makka. So if longitude of a 
country (or city) is equal to that of Makka, but their latitudes are not corresponding with each other, then the direction of Qibla would be on the Mid Day line. (There is one another point and that is the fact) that if the lands (where fixation of Qibla is required are lying in the North, their Qibla would be toward South and if these are lyin in he South, then it would be in he North. Similarly, if the latitudes of a country is the same as that of Makka but their longitudes are different, then they presume that the fixation of Qibla for that country would be on the "Equator" Line which s wrong presumption and "estimation".

Keeping in view the above-quoted saying of Imam Radi in mind, Mufti Muhammad Shafi' ${ }^{7}$ says:

"when the latitude (of a city) is equal to that of Makka but its longitude is not corresponding to that of Makka, then it is opined that the line of balance is toward the West as clarified by Allama Mashriqi to which Imam Radi has objected and called it wrong."

\section{DETAILED CRITICAL REVIEW OF THE AMBIGUITY IN THE DEFINITION OF QIBLA FOUND IN THE WRITINGS OF SOME OF THE HINDU'S \& ARYANIN WRITERS.}

Some Hindu and Aryan writers, in their assertions have tried to call th prayer offering of Muslims toward Qibla as equal to idol worshiping or idolatry. By this they mean to name Islam as a religion allowing practice of idolatry and it supports it. This objection and its reasonable answers are to be narrated in the following paragraphs:

\section{THE OBJECTION:}

"The Muslims call the Hidus idol worshipers (or people practicing idolatry), while the Muslims also offer their prayers duly facing a house which is built of stones etc, hence it is proved that that the Muslims are no less than the idol worshipers.

\section{THE ANSWER:}


To clarify the situation some points are reproduced here in the following lines which would prove that there is a big difference between "Idolatry" and only facing Qibla during prayers.

\section{FIRSTLY:}

Simply the word "Facing Qibla (استقبال الكعبة) and "Idolatry" are substantiating our proposition that "Idolatry" has no relevance with simply "facing" the Qibla (توجه الى الكعبة) while offering prayers • (These are very very two different things). Diverting faces toward "Qibla" means only to fix our faces on the direction to which the "Qibla" is lying during our prayers, while idolatry is "practically and truly worshiping an idol. (so these two acts are quite different.)

\section{SECONDLY:}

For fixation (Determination) of "Qibla" it is sufficient only to face the direction to which "Kabah" (Makka) is lying. There is no need of even making firm intention (or determination) of facing Qibla not even to speak of worshiping that. However, it is unavoidable for a Muslim to make a firm "intention" or determine (his whole hearted willingness) to worship Allah. Without pure and firm intention or willingness, no prayer of a Muslim is acceptable to Allah. It is proved from this "utterance" that the Muslims worship only Allah and not the "Kaba", while the firm determination (firm willingness) for the worship of Idols is the basic condition for idolatry.

\section{Thirdly:}

During the prayers the Muslims never utter such a single word which may indicate the "greatness of Ka'aba" rather their each word and act denote the meaning of the greatness of Allah only. In short, we can say that prayer offering of the Muslims is, from the inception to the end, an expression of the greatness of Allah and that of their humiliation as well as helplessness to Him. During this process even the name of "Ka'aba" in never uttered by the worshipers. Contrary to that in worshiping the idols, (or anything other than Allah), from the very beginning up to the end, the greatness of the said thing or idol is expressed or efforts are intensified by the worshipers to extent to please that.( that is why 
they have given such names to their idols which denote the meaning of "god"). In addition to that, they express their humiliation (humbleness) and helplessness before that body. That is why in idolatry, the greatness of those stones and idols is narrated which have already been named by them as "great gods" (un-true gods) by the people themselves. Same is the case with the followers of "Magus" (Zorastra) who idealize Sun as their "god' and worship the same in their worship place named "Gatheri". Also such like stones were being worshiped by the people in the past and their helplessness shown to them continuously. So it means that idolatry has no concern with the prayer (that is offered by Muslims).

\section{Fourthly:}

As per faith and practice of the Musims, it is not obligatory that during prayers they should compulsorily face the walls of "Ka'aba" physically. If supposedly the same walls are removed to another place, still the Muslims would continue to offer their prayers to same direction. They would not go to the other place where the remains of the walls of "Ka'ba" are placed. As once in the reign of Hadrat Abdullah Bin Zubair. ${ }^{9}$ (who was the grand son of Hadrat Abu Bakr. ${ }^{10}$, the first caliph and the son of the Prophet's SWAS cousin), it happened that he let fall the structure of "Ka'ba" to the extent that the first stone of its foundation was also dug out. This was done only to reconstruct the same in a perfect form, but during all this process, prayers were being regularly offered facing the same place as being in its old shape. If the walls of "Ka'ba" were ever intended to be worshiped or adorned, prayers should have remained suspended during the mentioned span of time, or at least the same (prayers) should have been revised or said the same late after the completion of the building, but none of the same happened. Had it been with the followers of idolatry, it would have stopped for some time. Furthermore, in idolatry the main aim is to bend before idols, offer prayer before them and worship them from the core of the hearts of the worshipers. This the reason that if ever somebody removes the idols from the Temple or Pagoda of Hindus and place them in another site, then all of their rituals and worships are to be offered in the new place and no one will bother about the old one. 


\section{Fifthly:}

The Muslims call "Ka'ba" as house of Allah and they do not call it "God" or Allah. It is an established fact that whenever a person goes to or visits a house, his main aim is the owner of the house to see and not the house. Similarly, whatever, compliments or greetings etc are offered by a person there with great submission; all of them are for the master or say the occupier of the throne and not for the throne or house. This fact is so obvious that a mad man also cannot hesitate to understand and accept it. So we may consider the offering of prayers toward "Baitullah" (Ka'ba) in this context and should not fall prey to the other possibilities(حتملا).

Exactly in the same way take the act of offering prayers in the direction of ". out of so many other things, the word "Baitullah"( is also an indicator to the fact (subject to possessing reason and wisdom)that here master of the house is aimed at and never ever it meant the house. It is quite clear that the idol worshipers themselves do not take their idols for house of the god or the chair of god or throne of God rather they take them for "Maha dev" or "Shub" or "Ganesh" etc. Since these great people are considered liable to be worshiped, hence in the process of idol worshiping the main objects are those idols.

\section{Sixthly:}

According to the Muslims' beliefs, the worship worthy is that personality who is self existing and all others are in need of His assistance to come into existence. His authority alone has control over their benefits and losses, but His 's are not controlled by anybody. That Allah whose perfection, beauty and greatness are His own characteristics imbibed by Himself without the assistance of any one. In their (Muslims) view according to the substantiation of traditions and reason no one else Him is possessing the same tributes. In these conditions the worship that is practiced by the Muslims, cannot be taken for anyone else except the One Allah. However, according to the belief of the majority of Hindus the only One God (Allah) is not liable to be worshiped. The gods who are intended to be worshiped are "Mahadev", "Bishin" and "Barihma". Because these people call "Allah" "Akarta"(that who does not do any thing) and therefore, they consider the said idols to 
be mostly responsible for the good and bad done with the people in this world. It is a commonly known fact that worship is the name of "submission and complete obedience". For this type of submission, it is very much necessary that the thing or person who is being worshiped, there must be a hope of receiving some benefit from him or a fear of some damage. Due to this reason it is quite evident that the submission shown by the servants to their master is simply on account of that hope and the obedience of subject or helpless people (to the ruler) is for the reason that they are afraid of him. So far pleasing the "beloved" (ie here god or Allah) is concerned, in this situation no hope like that of servants or a fear like that of subject and helpless people are found. But when it is observed that the desire for availing a loved thing (or person) is called "hope" and the fear is the "losing of the loved one", so this rule is visible in the obedience of lovers at the highest level. However, it is a fact that the base of submission (obedience) is the "hope" and "fear". Since these two characteristics, according to the faith of polytheists are closely related to "Mahadev" and "Bishin", and these have no relevance with Allah, hence it should have been made mandatory that the "Mahadev" etc should deserve to be worshiped excluding Allah to be worshiped at all. In short, as per view of the Muslims "Ka'ba" is not to be worshiped, while according to the majority of Hindus idol is deserving to be worshiped or adored, because as per their presumption they take them for the "Great Idol". It is proved from this statement that calling "Ka'aba" to be the place to which adoration or prostration is made is wrong, but rather we would have to call it the "direction or place of prostration or adoration". In addition to that the "idols" would be called to be bodies to which prostration or adoration is (directly) made by the Hindus.

\section{Seventhly:}

(As per Arabic Grammar) a verb (in a sentence) remains sometimes, under the influence of a role of its subject or that of an object . so when we analyzed "knowledge" and "Order" hence we found the first one to be subordinate to the "known" and "order" is subordinate to the "Ruler" (or the person who has the authority). It means that there is no role of the agreement and authority of the scholarly person in "ilm" (knowledge), as it appears and it becomes public it becomes corresponding to the same. If mistakenly "Ilm" (knowledge) is contrary to the known (thing) it is 
not an "Ilm" rather it nominal "Ilm". On the other hand in the case of Order (Hukam) the "Hakim" (the person responsible for issuing an order) is free to issue any such order which he likes. There is no influence of the like dislike of the "mahkoom" (subject or subordinate) and in his order. Rather for the subject it is mandatory to obliged to obey the order of the "ruler" immediately after having received or heard the same without any question or query. In addition to that whatever he listens (from the ruler or chief officer), he should abide by the same. Also he should start thinking about acting upon the same order just after listening the same and considering the order of the ruler as situation where people say: it is the time to do or die. He should become helpless and should not move without having obeyed the order of his high authority. However, if the order issued so far is based on such a knowledge or belief which is against the existing realities, he should take that, without any hesitation, for a satanic deception and should never fall prey to any doubt that it may be the saying of Allah which may cause people bear the trouble of investigating its state of the affairs. Because, it is important to point out that "Ilm" (knowledge) is compulsorily subordinate to the thing which has to the public it is not like "Hukam" (order) which is subordinate to the higher authority. In that case when it is a "Hukam" (order) of the higher authority, the subordinate has no option to obey whatsoever may be the conditions. If this is the condition, then in placing our faces toward the direction of "Ka'aba" is unavoidable to be obeyed. However, this much investigation is necessary to prove whether the order issued so far is that of Allah or not?

The reason is that seeing the same order it is proved that the order under reference is not based on any such thing which is contrary to the realities, rather no need of narrating any incident which is against the common belief so its obeisance is essential and mandatory. No need of even presenting facts (proofs) pertaining to beliefs, there is only need of the fact that the order is that of Allah, because the aim of facing "Ka'aba" during prayer is only that the same "simat" (direction) is fixed as "Qibla" for worshiping. So there is no need of "اعتقاد" (faith \& will), only the instructions of Allah are required which have already been issued. However, if in Islam only by facing "Ka'aba" (Qibla) adoration or prostration had ever been intended, then like idolatry here too we would have been in need of the believing that "Ka'aba" is liable to be worshiped, but according to the belief (faith) of the Muslims the 
aim of facing "Ka'aba" or "Qibla" is base on the fact that all prayers should be offered its direction.

From all of the above statement it is intended to point out the difference between worshiping idols and offering prayer toward "Ka'aba". In idolatry the worship is for "somebody" (here the idol) while offering prayer to the direction of "Ka'aba" the worship (or say adoration) is for "Allah" alone. Furthermore, as worshiping Allah according to all sane people is a good behavior acceptable to all and sundry, but worshiping anything without Him is an acceptable behavior and it is considered a bad thing, hence the answer to the above narration shall be nothing but to call it an "Allegation" or deflation of the Muslims.

Besides the above questions answers and reasons (as narrated above), a research based response is also being presented in following lines (to clarify the topic)

\section{Response based on research duly verified:}

The Muslims believe that "Ka'aba" is not the thing (or place) which is (solely) meant to be adorned or prostrated, but rather they consider it the place of the "تجلى (manifestation) of Allah and as manifestation is like the real appearance of a thing, hence prostration or adoration to it stands for prostration and adoration to Allah.

The proof for being the picture or manifestation of a thing like a real thing is that if the same ever happens not to be the real one, then the recognition of the real thing would become difficult with the help of the "manifestation" (picture), it would result in becoming each "manifestation" (picture) as body or picture of any other real thing (and difference would also become difficult).

When unification of the two is not a condition, then it is meaningless because a picture in spite of variation is a source for recognition and the picture of Zaid (for example), is not a mean for recognition of the picture of "Amro". However, if it is said that the picture given at two places is the same, but the persons are different from the pictures or say the manifestations are different then this recognition would also be considered as correct. Consequently, the variation found in the pictures would also be settled and its reason would also be identified, because everyone says about a picture that it is the picture of a such an such person. 
So saying "to be true" is also because of the fact that it is established in each heart and the same saying is on the tongue of each one so its reason is also the unification of the picture with the real thing.

The reason of being "Ka'aba" a manifestation of the Lordship (of Allah) or "تجلىربأنى is that the relevance which is found between a mirror and a light, the same is found between this atmosphere (the vacuum visible between the earthe and sky wherein all bodies are accommodated) and the body too. Ordinarily all objects are the bodies of light (luminosity); and due to this reason these all are felt by senses; and if the same is not existing, then there is no possibility of the visibility of the shapes and colors of the bodies. The body looks as a light in reality and on account of the same all this colorfulness exists

Despite all of this combination and association, the nature of the relevance of the mirror with the light is stronger than its relevance with other bodies. The light and mirror both are equally perceptible. Similarly, light is also quite clear and transparent (is not barrier against the penetration of the sight) and mirror is also clean as well as it does not bar penetration of sight. If any cleanliness is found in the air, so that is not perceptible and the bodies other than these though they are perceptible but not clean enough. So the result of this cleanliness and feeling is that "mirror" becomes the place where manifestation of light occurs. Similarly, due to this the thing which can be seen through eyes that becomes visible in the same light which is available across the mirror in the atmosphere." هنالقياسعليو" (so on and so forth).

By the way all creature are the bodies and on the same basis all " "احكام وجودى Omni Orders are further divided differently according to their different nature (otherwise all the creatures would use to come into existence on their own on their own consideration, consequently, the body as that exists it would have been Immortal like the "Omni Present"مو جوداصليهو". In spite of the fact that all creatures are associated with each other on account of being one unity, but in the same atmosphere the relevance that is found in the existing thing with the created things that is not available in the other things يهابلامشار.

\section{DETAIL EXPLANATIONS OF THE PROPOSITION}


A. All common bodies of the universe are dependent in their existence on Him and have no concern with other things, also all of the humans are in need of His assistance in their creation and extension of their lives.

B. As the "Existance of that One Body" is unlimited and infinite, similarly the said atmosphere is also unlimited and infinite.

The reason for the "Body" being unlimited or infinite is that if it is made limited and finite then it would have been obligatory to enclose Him in a certain enclosure. So far enclosure is concerned it is not possible to separate a small thing from a very big thing on the basis of the same enclosure, therefore first an infinite thing has to be accepted by the human mind there after the stage of an enclosure would come. So based on this theory for each قيu"م", "conditional situation or thing" there must be an absolute one, but when due to necessity it is of use in "مطلى" (absolute) then it would also help in "infinite" (متاهيل). It means that whenever there is an "Infinite" there must be a "Finite" before that where in a "finite" is chosen on the basis of the said "infiniteness" and "openness),but when we saw the "existence" of things we found no meaning a thing before it. In these conditions how can that thing become a limited one. If we call it "limited" or "finite", then we would be compelled to believe in one another meaning beyond.

But when due to this reason there is existing a"body" which is infinite and unlimited, then:

- The related "atmosphere" should also be infinite otherwise beyond its limits other extensions would have to be believed which woud be infinite in itself or another infinite extension other that that would have to be believed. In short if the said atmosphere is not "infinite" then another atmosphere, an infinite one would have to be accepted for this atmosphere. Therefore, it is better to believe in its being "infinite", otherwise for this atmosphere another "infinite" atmosphere will have to be recognized for the same, also it would cause such a situation when we would have to believe in the fact that for heat there would be another heat and for one coldness there would be need of another coldness. 
C. As (if) a "body" is not movable, in this way the atmosphere will also not be movable:

The concept that atmosphere is not a movable thing is a heartening idea, but the second thing is that for moving it is necessary that it appear that the things are such objects which are placed in a container and that container is the "Atmosphere" wherein compulsorily movement in- conceivable.

Having explained that it is respectfully stated that these causes are common in the atmosphere and the "body", but these are not existing in the bodies other than the same. So it is just like the same situation which is between the mirror and the light as mentioned earlier. Therefore, as the mirror had become the manifestation (of light) due to the known relevance and existing (at that time) of the object concerned, hence in this way it is also obligatory that due to the presence of the same conditions, the atmosphere may also become a manifestation of the lights. For that reason before hand, the things which are in the circle of existence and they may confront the atmosphere, they would reflect in the same.

When the "body' or existence of athing was seen, its relevance with the "godly grace" was just like the relationship of the rays with the Sun. It menas that the rays can never be separated from the sun and the structures (bodies) found in the universe get bright due to its occurrence, connection and coming into being. They get separated from them in the same way as they earlier were similarly, the "Body" (of Allah) does not separate from them, but the things which come into existence due to Allah's presence and their connectivity with other things etc ie these creatures ( of the universe) get separated from Him as these were earlier. Allah remains alone without any one else with Him. Due to this reason all the creatures diminish with the passage of time, but when this situation is proved then it is also a fact that as the rays of Sun encircles the Sun (itself), in his way the same body would be acting as a circumference for the "grace" of Allah. That is why it is expected that the reflection of the same would once appear in the same atmosphere, but as for the reflection of the mirror there is the conditionality of its "confrontation" (toward light), in this way the mirror is in need of "قلى" (tinning/plating). It addition to that, for the emergence or creation of reflection or in the said atmosphere, the confrontation of the same with the light is a pre-requisite " مناعلى" القياس" (so on and so forth). Hence, there must be some 
dark thing instead of tinning, due to which the seeing power should not penetrate further and as a ball it strikes a thing and rebounds back; and lays on the real (original) thing and due to eye sight reflection , a satte of "inversion" is produced. In short, we say that as for apparent visibility, tinning or plating is a mean of producing darkness, in this way there must be another source to cause invisibility in the "insight" instead of eye sight. So the matter that causes darkness is that "nothingness")(علم) which encircles those "confined special creatures or creations" (which includes the said atmosphere too) in the same way as the "sunlight of the compound" covered by the shade found there. The darkness as mentioned above is no less than any other darkness and the satte of its comparison is that as the "beauty of the Sun" is the beginning of the said "body", in the front of which the beginning of another thing is also required. So when "اللهكعبة" (the Ka'ba) had come first to the surface or its existence was seen by the people, so simultaneously the "beginning" of the world had also emerged. The reason is that this incident is the story of the by- gone times and for discovering the past events, there is no other state of affairs except the fact to learn from the "well known" traditions and trustworthy narrators. Hence, in this connection nothing better (books or narrators) could be found than the "Holy Quran" and Muslim Narrators (of Hadith).

The state of the safety and protection of the Quran is hither to well stated by the presence of thousand of thousand "Hafiz Quran" and through them it is known to all that in the past eras the same method was being followed. Amongst them the nature of managing memorizing traditions (حفظ روايت) was such of high standard that they would ascertain the races, residences, characters, (honesty and justice), mental power, (state of) God fearing, the era and the category of the narrators. They would always consider these all matters while making clear any doubts related to any issue. ${ }^{11}$ The First Ever foundation in the World is that of "Kaaba" (بيتالله) Quran says:

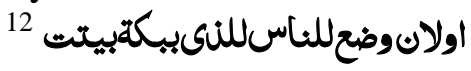

In some Ahadith this has been narrated that before the creation of the present structures there was water and water everywhere. There, for the first time a bubble or was seen at the place where lies now the "Ka'aba" and from there the foundation of the earth 
took evolving. It means that the said verses and ahadith prove that this piece of the land and this "house' is the beginning of the all universe. That is why a comparison between the "beginning point" of the Universe started with this inception of the earth \& the sky. Then there is no possibility of covering things at the time when all has been clearly opened for all, otherwise the as if the earth is covered up the Sun light would have no effect on it, in this way covering of all creations would terminate the possibility of their coming into being. In short when there is no "Curtain" (Hijab) then if all these things are present ie: "confrontation", "capability of reflection', and "the things necessary for darkness" so what then it means that there would not be any reflection? (it means reflection would definitely happen). Therefore, it has dawned upon us all surely that in the "atmosphere of Ka'aba" there exists the "godly manifestation" (of light) and that is neither confined in the atmosphere nor in (any) direction. Had it been confined in the atmosphere etc then it would have been obligatory to call the reflection of Sun to be confined in a mirror while it is quite clear from the volume and structure of the mirror that it has no capacity of accommodating the Sun or its reflection rather that is only a manifestation of the same. So, if the mirror is a "Manifestation" and it does not encircle the the reflection or its origin, then the said atmosphere should also be considered as a manifestation and a not a circumference which may cause the confusion about Allah 's exemption from all such characteristics. He is in totality the "Object of worship" (Manifestation of lights), the said atmosphere is is its manifestation and the walls are its limits. The walls are not intended to be the "object of worship", however these are no doubt, "the objects toward which worship is directed". When the walls are not "the object of worship" and the thing to be worshiped so taking walls for idolatry equalizing that respect of "Ka'aba' with idol worshiping is nothing but a vain thought (misgiving). No one can say that (in idolatry) worship is being done toward it (مسجوداليه) and not like a "Lord to be worshiped directly", because first of all the word "idolatry" and the intention of idol worshipers are witness to this that they worship them. Secondly, the idols do not have the capability so that they may become "godly manifestations" by themselves replacing "the real Allah". The reason for this is the fact that they do not have the relevance which is found in the elements of manifestation which is quite clear from the lack of presence of the relevancy in them (as already discussed earlier). 
Based on these comments it also cannot be claimed that idolatry (as manifested by the present day polytheists) is no doubt an infidelity and baseless polytheism. The fact is that the idols (before the advent of Islam) were in a position to the direction of whom, the people would face and worship them. Then the ignorant and illiterate people replaced them with the "objects of worship". If now somebody presume the idols to be "object of worship" and offer their prayers accordingly so what is the harm in it? (So the detail is) It is essential for the object to the direction of which worship is offered, that it should be "manifestation" otherwise the becoming of "object as worship" would prove wrong. When this principle had already been determined that for each "object to the direction of which worship is offered" is in need of a (real) "the thing being worshiped" (Allah) or its manifestation. While it is also a fact that among the idols the "objet of worship" (the real one) cannot manifest in them, then this excuse which is the worst of all cannot be presented to say that the ignorant have made the idols "object of worship" while as a matter of fact they were (taken for) "the object to the direction of which only prostration was being made. ${ }^{13}$

\section{References:}

${ }^{1}$ (www.allamamashriq.info) He was born on 25 August, 1888 in Amratsar. He did his MSC from the University of Punjab. He had been the founder leader of "Khaksar Movement". Amongst his contributions, "Tadhkirah" and "The wrong Madhab of the Molvi" are very famous. He died in 1963.

${ }^{2}$ Al-Baqarah:144.

${ }^{3}$ Sunan Ibn-e-Majah, (56), "Bab Al-Qibla" (1) 323.

4 Mashriqi, Inayatullah, "Molvi ka Ghalat Madhab", Al-Tadhkirah Pubications,34-Zildar Road, Lahore, No year of publication.

5 Razi Fakhruddin Imam, "Muqaddamah tafseer Mafatih Al-Ghaib", volume 4,Dar Ihya'a Al-Turas Al-arabi, no year of publication. (Imam Razi's full name is Muhammad Bin Umer. He was one of the great Mufissrin of Quran in the sixth and seventh Century. "Tafseer-e-Kabir' is one of his great academic creations, the explanations of which upto "para $26 "$ is done by him in person. After his death in $606 \mathrm{AD}$, his pupils wrote the Tafseer of the remaining 4 parahs on his pattern. His (Fiqhi Maslak) was Shafia.). (He was the follower of Sahfi "Fiqh"). 
${ }^{6}$ Al-Razi, Muhammad Bin Umer, "Tafseer Mafateeh Al-Ghaib", volume 4, page 101, Dar Ihya'a al-Turath-Al-Arabi" (no year of Publication).

${ }^{7}$ His anme was Muhammad Shfi'a Bin Maulana Muhammad Yasin, born in 1314 Al-Hijrah. His place of birth and city of residence was (probably) predetined by Allah to be Deoband-the center of Islamic Studies. Amongst the list of his teachers names of the great Ulema like: Maulana Mahmood Al-Hasan, Sha Anwar Shah Sahah Kashmiri, and Mufti Aziz Al-Rahman are worth mentioning. (Similarly), the books like "Tafseer-i-Ma'arif Al-Quran", "Ahkam-Al-Haj", "Alywaqeet Fi AhkamAl-Mawaqeet" and "Ilsamic Zabeeha" are his mentionable contributions. He served "Dar Al-Uloom Al-Deoband" as faculty member for 26 years . there after he migrated (to Karachi) and established "Dar Al-Uloom Karachi". He (served here and ) lived here for the rest of his life until died at the age of 83 years. (Muqadama Tfseer Ma'araif Al-Quran, page:60, "Idarat Al-Ma'arif Karachi", February 1982 AD).

${ }^{8}$ Mufti, Muhammad Shafi'a, Jawahir Al-Fiqh" Page: 299, Maktabah Dar Al-Uoom Karachi, 1482 Alhijrah.

9 The year of the death of Syeduna Abdullah Bin Al-Awam Bin AlKhwalid Bin Asad Al-Qarshi is 83 Hirah. He was the first to have bennborn in Madina just after Hijrah to it. He was the cousin and great supporter of the Prophet (SAWS) Zubair Bin Awam. He was an experienced horse rider and great knowledgeable person. The people agreed upon his Caliphate in 64 of Hijrah. He happened to fight with the Umayyad so many times and was martyred by Hajjaj Bin Yusuf . there are 33 Ahadith reported from him. (Al-Isabah: 309:2, "Shazarat AlZahab" 306:1, "ser Ielam alnubala'a 363:3, "Wafiyat Al-A'ayan" 71:3.).

${ }^{10}$ His name was Abdullah, his father's name was Uthman Ibn Abu Qahafah and "kunniat" was abu Bakr. His two appellations (Laqabs) were known among the people, one was Siddiq (the righteous) and the second was "Ateeq". He was among the greatest Companions of the prophet (SAWS), a caliph and one of the great "Asharah Mubasharrah". He was the leader of those companions who were the great experts of "Knowledge of Genealogy" . he was older than the Prophet (SAWS) by 2 years and four months. The Prophet Muhammad was born in the year of "Ashab Al-fil" (the year of the attack of Elephant". After 2 years and 4 months, Abu Bakr was born.there after the Prophet (SAWS) died in the month of Rabi-Al-Awl' in 11 Al-Hijrah, while syeduna Siddiq died in Rabiu-al-Akhir, 13 Al-Hijrah. He was the first among the men to have converted to Islam. He was a thin and kind hearted but very brave person. He remained always by the side of the prophet (SAWS) even in the travelling and at home. Last but not the least his grave is also by the side of the prophet's grave and they both will resurrect from their graves on the day of Judgment collectively. (Al-Aka bir: page:19). 
11 Nanotawi, Muhammad Qasim, Qibla Numa'a, page: 3 to 25, differently, "Kutub Khana I'a zazia Deoband". (No year of Publication). ${ }^{12}$ Al-Imraan: 94.

${ }^{13}$ Nanootvi, Muhammad Qasim, Qibla nma, Page: 3 to 25 differently, "Kutub Khana I'azaziah Deoband" (No year of Publication). 